\title{
Assessment of Employee Recognition on Performance of Organization: A Case of Meru Water and Sewerage Services
}

\author{
Betty Karwitha Mwiraria ${ }^{1 *}$, Dr Appolonius S Kembu, $\mathrm{PhD}^{2}$ \\ ${ }^{1}$ Masters of Business Administration, Mount Kenya University, Kenya \\ ${ }^{2}$ Lecturer School of Business and Economics, Mount Kenya University, Kenya
}

\begin{abstract}
Employee recognition is critical in all firms in Kenya, especially those that are growing. This is due to the fact that staff turnover is high, as workers look for better opportunities elsewhere with higher pay and benefits, or as employees are headhunted by competitors. With this in mind therefore that this study will investigate effect of employee recognition on performance of organizations. The objective of the study was; to determine the influence of recognition of employees on performance of organization. Using Herzberg's two-factor theory as its foundation, the study used a descriptive research methodology with a target sample of 150 workers from Meru Water and Sewerage Services. The major data collecting tools were questionnaires, which were validated and reliable via a pilot study. A regression model was used to establish the link between research variables and organizational performance, and the results were presented in a table. Results of the study revealed that recognition had a positive and significant impact on the performance of the organization, as indicated by the $t$-values of $(t=2.817, p 0.05)$, on the organization's performance. According to the findings of the research, acknowledgment is critical in improving employee performance, which in turn improves the performance of the firm. In addition, the researchers discovered that workers' performance would improve if they are properly and promptly rewarded for their efforts. According to the findings of the study, MEWASS management should make every effort to provide recognition that will attract, retain, and encourage its employees in order to assist them in working in a conducive environment that will improve organizational performance.
\end{abstract}

Keywords: Employee recognition, performance, Herzberg's twofactor theory, and descriptive research methodology.

\section{BACKGROUND OF THE STUDY}

$\mathrm{O}$ rganizations nowadays have a critical challenge in terms of employee recognition, which is critical since workers are the most important assets a company may have. Companies should succeed, according to Boyens (2007), when they are able to retain their most skilled personnel rather than recruiting and training new staff. Successful and highly productive organizations are built by encouraging people to enhance their performance. In order for the company's competitive advantage to be maintained, all employees must make a thorough commitment to meeting the performance standards set out (Breaugh \& Frye 2008). It is possible to improve the performance of a company by providing employees with access to critical resources, empowering them, and expanding their knowledge and talents, as well as through boosting employee morale and changing their attitudes and viewpoints. Horton (2007), in his study of interindustry variation in male and female employees turnover in manufacturing companies in the United Kingdom (UK), discovered that the annual late on employee turnover in men was lower than female in the oil refineries industry and higher than female in the jute industry in American cooperative companies, among other findings. As a result of the high female employee turnover rates in fruits and vegetable product firms, the researcher came to the conclusion that male employee turnover rates across all manufacturing enterprises were lower than female employee turnover rates.

The major objective of every firm is to prevent the loss of competent employees, which might have a detrimental influence on productivity and service delivery (Mitchell \& Erez, 2001). As defined by Ongori (2008), a reward is anything that a firm provides to an employee in order to motivate them to perform their best work in the future. The company recognizes and rewards employees that go above and above in their jobs in a variety of ways, including cash, free gifts, and even trips to exotic locations across the world. Employees' accomplishments and successes may be recognized with anything from a little token to considerable cash, depending on the worth of their contributions and achievements.

\section{Statement of the problem}

Employee recognition is impacted by a wide range of factors, including compensation and benefits. As far as their job and obligations are concerned, people have become more demanding of themselves (Ming, 2008). Recognition of employees is a method used by businesses to boost their overall productivity. Researchers, practitioners, and academics have discovered a correlation between employee recognition and desired performance (Harris, 2000).

According to Ming, (2008), if an organization's incentive systems are adequate, not only does it improve equity, but it also increases employee recognition. They observed that job satisfaction and acceptable human resource policies are positively related to employee recognition. Research undertaken by Robbins (2003) demonstrates that a focus on 
employee recognition is critical for the long-term health of academic institutions, as shown by the fact that academic staff turnover is closely tied to the leadership style adopted by the institution.

High worker turnover has been a source of worry for many in the corporate community. If their needs are addressed, it is unlikely that employee turnover will become a problem. According to the growing rate of labor turnover, some individuals are unsatisfied with their current employment. As a result, a study was conducted to determine the influence of employee recognition on the Meru Water and Sewerage Services' ability to function.

\section{General Objective}

The purpose of this study was to assess the effect of employee recognition strategies on organization performance.

\section{Significance of the Study}

The study will provide information to both public and private organizations on the importance of providing appropriate employee recognition strategies that enable them retain their competent workforce for effective organizational performance.

The research study will provide areas for further research that can be used to give more insight in this area of study and form part of the literature review on this area.

\section{LITERATURE REVIEW}

Allen and Renn (2003) conducted a study titled "HR Practices and Employees Recognition, an Empirical Examination of the Pharmaceutical Industry of Pakistan" in which they added perceived organizational support as a mediating variable. The researchers used a convenience sample of 100 sizes for their study, and they investigated the majority of secondary sources. A significant predictor of perceived organizational support was found to be the possibility for future growth in the study. According to the results of the research, employee turnover was shown to be negatively connected with development opportunities and fair remuneration, but employee recognition was found to be positively and significantly correlated with both growth opportunities and fair compensation. They discovered that, in order to retain bright employees, there must be opportunities for promotion as well as an appropriate reward plan for their efforts.

Chidinma (2012) investigated the impact of reward management on the performance of University of Nigeria Nsukka employees for the objective of this research. Research done by researchers from the University of Nigeria, Nsukka revealed that incentives, whether financial or intangible, had a positive impact on employee performance.

Compensation, including both extrinsic and intrinsic motivations, cash rewards, and recognition, as well as working environment and leadership styles, all have a significant influence on job performance. making employees feel that their contribution is valued by providing them with more freedom and autonomy inside the organization and by incorporating them in decision-making (Ndungu, 2017).

\section{Theoretical Framework}

The theory provides managers with an overview of the factors that influence employee motivation and demotivation. According to Herzberg, the behavior elements may be divided into two (2) categories: cleanliness and motivators. Herzberg's theory (1974) states that the hygiene variables are those that, if satisfied, will meet the requirements of the employee; they include the fundamental necessities, working circumstances, and motivators of the employee. If they are not addressed, they may cause people to become demotivated in their jobs, leading them to lose faith in the company and seek other employment options (Breaugh, 2000).

Human beings, according to Herzberg (1959), are not happy with the fulfillment of lower-order needs at work, such as those connected to minimum wage levels or safe and pleasant working conditions, but rather are motivated by advancement and the nature of their work. This seems to be consistent with Maslow's hierarchy of needs concept so far. A consequence of Herzberg's two-factor model of motivation, employees are said to be more contented at work when certain qualities or incentives of their occupations are present, but dissatisfaction with one's employment is produced by another set of characteristics or incentives, according to Herzberg (1959).

Job happiness is influenced by a number of motivator variables, which include achieving goals, having development chances, being recognized, and having a sense of responsibility. Dissatisfaction is avoided via the use of hygiene factors, but staff motivation and productivity are increased through the employment of motivational elements. It is consequently critical to discover methods of motivating people to continue working in a company's environment.

\section{Conceptual Framework}

The conceptual framework was drawn directly from the research topic.
Independent Variables

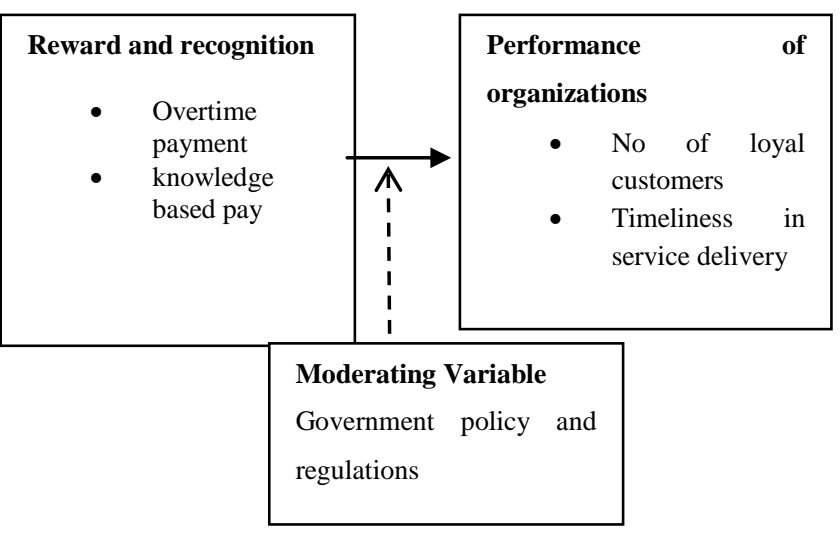

Figure 1: Conceptual Framework
Source: Researcher (2021) 


\section{METHODOLOGY}

\section{Research Design}

This study employed descriptive survey design since this design is customized to gather data from a sample analyse it and make inferences about the entire population. This research design was relied on to investigate effect of employee recognition on performance of organizations using case of case of Meru water and sewerage services. This design was deemed appropriate since the study sought to establish the current state of affairs without interfering with the situation.

\section{Study Area}

MEWASS may be found in Meru County's Meru Town. Under the Trustee Act (Perpetual Succession) Cap 164, MEWASS was established on July 24th, 2001. The Trust Deed and Constitution of MEWASS set out the regulations for the MEWASS Trust to follow. Following formal recognition and gazette on June 15, 2002, MEWASS assumed control of the Meru municipal water and sewerage system on July 1, 2002, from the Meru Municipality Council and the Ministry of Environment and Natural Resources. A Service Provision Agreement (SPA) between the Tana Water Services Board and the MEWASS Trust mandates the provision of water and sewage services in Meru and its surrounding 140 square kilometers. The Meru County Government has taken complete ownership of the utility.

\section{Target Population}

More than 150 people work with MEWASS, according to the Human Resource Management department. There were consequently 150 workers at MEWASS, Meru County, who were the focus of the study. To better understand how to retain people, the research focused on employees in the three management categories. The target population was divided into three categories as shown in Table 1.

Table 1 Target Population

\begin{tabular}{|c|c|}
\hline Category of Population & No of staff \\
\hline Top Management Staff & 6 \\
\hline Middle Level Management & 24 \\
\hline Lower Management & 120 \\
\hline Total & $\mathbf{1 5 0}$ \\
\hline
\end{tabular}

Source: MEWASS, (2021)

\section{Sampling Procedure and Technique}

The unit of analysis was MEWASS in Meru County, which was based on the census. Specific sample designs and techniques were not applicable since they were ruled out in this case. In order to collect data from all 150 MEWASS personnel, the researcher used census.

An advantage of conducting a census is that it enables researchers to observe and collect data on smaller geographic units. According to Orodho (2009), data collected by census contributes to the collection of impartial data expressing the perspectives of all persons within the research population on a study topic, hence this method is appropriate.

Groups were formed based on the hierarchy of power inside the organization.

The three levels of management that were implemented were: top, medium, and lower.

\section{Research Instruments}

This study relied on a semi structured questionnaires to collect primary data. The instrument provided section where section A was used to explore demographic characteristics of the study respondents as well as obtain views and opinions on the variables under study. The remaining sections were based on research objectives. Responses provided on the various variables of the study were measured on Likert scale for the closed ended.

\section{Data Analysis}

Cleaning of data was done before analysis by doing the corrections or removal of data that had error due to contradictions, duplications, answers that are ambiguous and incomplete information. Collected data was then put together, given codes and responses examined with regard to research questions. Data from the field notes and the transcripts of the audiotapes was analyzed. Data that is quantitative in nature was processed using the Statistical Package for Social Science (SPSS) Version 25. The quantitative data was presented in frequency and percentage distribution tables.

Regression model was applied to determine the relationship between independent and dependent variables.

$\mathrm{Y}=\beta_{0}+\beta_{1} \mathrm{X}_{1}+\varepsilon$

Where

Where: $\mathrm{Y}$ is performance of employees; $\beta_{0}$ is the constant or the intercept of the regression line; $\beta_{1}$ is regression coefficients for predictor variables; $X_{1}$ is recognition of employees of employees; $\varepsilon$ is the error term.

\section{Response Rate}

There were six top-level managers, 24 middle-level managers, and 120 lower-level managers in MEWASS who participated in the research. All respondents were sent a 150-question survey, and 118 of them returned it, which indicates a response rate of $78 \%$. If a response rate of $50 \%$ is acceptable for analysis and reporting, if a response rate of $60 \%$ is good or better, and if a response rate of $70 \%$ and above is very good, then the results are excellent. Because of this, the total response rate of 78.67 percent was acceptable.

\section{Descriptive Analysis}

Statistical Package for the Social Sciences (SPSS) version 24.0 was used to show the quantitative data using descriptive statistics such as the mean and standard deviation. In accordance with the study's goals, they were presented as follows. 


\section{Recognition and performance of organization}

Research found that recognition is a factor that affects an organization's performance. It was determined that recognition feature affects the performance of organizations by measuring the amount of agreement that respondents had with the given assertions. According to a Likert scale of 1-5, respondents indicated how much they agreed or disagreed with the assertions. Accordingly, the values were coded as follows: 5-strongly agree; 4-agree; 3-neutral; 2-disagree; and 1-strongly disagree. For each statement, we calculated the mean score and standard deviation and summarized it in the table 2 below.

Table 2: Recognition and performance of organization

\begin{tabular}{|c|c|c|c|}
\hline \multicolumn{4}{|c|}{ Descriptive Statistics } \\
\hline & $\mathbf{N}$ & Mean & $\begin{array}{c}\text { Std. } \\
\text { Deviation }\end{array}$ \\
\hline $\begin{array}{c}\text { Benefits that employees are } \\
\text { supposed to get are paid promptly }\end{array}$ & 118 & 4.11 & .840 \\
\hline $\begin{array}{c}\text { Recognition of employees results to } \\
\text { good organisational performance }\end{array}$ & 118 & 3.81 & 1.015 \\
\hline $\begin{array}{c}\text { The organisation has incentives for } \\
\text { employees who contributes highly } \\
\text { to organization performance }\end{array}$ & 118 & 3.54 & .864 \\
\hline $\begin{array}{c}\text { Salaries and benefits are paid } \\
\text { regularly }\end{array}$ & 118 & 3.42 & 1.024 \\
\hline $\begin{array}{c}\text { Employees are fairly rewarded for } \\
\text { their perfomance }\end{array}$ & 118 & 3.39 & .979 \\
\hline Valid N (listwise) & $\mathbf{1 1 8}$ & & \\
\hline
\end{tabular}

Source: Researcher (2021)

The results in Table 2 indicate that majority of the respondents strongly agreed on the statements that benefits that employees are supposed to get are paid promptly indicated by a mean of 4.11 and a standard eviation of 0.840 and that recognition of employees results to good organisational performance was ranked second as indicated by a mean of 3.81 which varied significantly as indicated by standard deviation of 1.015. These were followed by the statements that the organisation has incentives for employees who contributes highly to organization performance $(\mathrm{M}=3.54$, $\mathrm{SD}=0.864)$, regular payment of salaries $(\mathrm{M}=3.42, \mathrm{SD}=1.024)$ and employees are fairly rewarded for their perfomance $(\mathrm{M}=3.39, \mathrm{SD}=0.979)$. These findings concur with the findings of Chidinma (2012) which revealed a great a relationship between monetary rewards and non-monetary rewards on employee's performance among staff in University of Nigeria Nsukka. Nyanjom (2013) indicate that a significant relationship between job performnce and extrinsic and intrinsic such as financial rewards andrecognition.

\section{Regression summary}

Linear regression analysis was used to test the relationship between employee recognition and performance of organization in MEWASS.
Table 3: model summary

\begin{tabular}{|c|c|c|c|c|}
\hline \multicolumn{5}{|c|}{ Model Summary } \\
\hline $\begin{array}{c}\text { Mod } \\
\text { el }\end{array}$ & $\mathrm{R}$ & $\begin{array}{c}\mathrm{R} \\
\text { Square }\end{array}$ & $\begin{array}{c}\text { Adjusted R } \\
\text { Square }\end{array}$ & $\begin{array}{c}\text { Std. Error of } \\
\text { the Estimate }\end{array}$ \\
\hline 1 & $.850^{\mathrm{a}}$ & .695 & .722 & 1.006 \\
\hline a. Predictors: (Constant), Employee recognition \\
\hline
\end{tabular}

Source: Researcher (2021)

The coefficient of determination (R-squared) was $72.2 \%$ as indicated by the adjusted $\mathrm{R}$ squre. This means that the independent variable i.e. recognition, was studied and explained up to $72.2 \%$ of changes in performance of organization a case of MEWASS in meru county.implying that there are other factors not studied in this research that contribute to $(27.8 \%)$ of performance of MEWASS. This therefore calls for further research should be conducted to investigate the other factors $(27.8 \%)$ that affect organisation performance in MEWASS in meru county Kenya.

Table 4: Analysis of Variance

\begin{tabular}{|c|c|c|c|c|c|c|}
\hline \multicolumn{8}{|c|}{ ANOVA $^{\text {a }}$} \\
\hline \multirow{2}{*}{ Model } & $\begin{array}{c}\text { Sum of } \\
\text { Squares }\end{array}$ & df & $\begin{array}{c}\text { Mean } \\
\text { Square }\end{array}$ & F & Sig. \\
\hline \multirow{2}{*}{1} & $\begin{array}{c}\text { Regre } \\
\text { ssion }\end{array}$ & 13.692 & 4 & 3.414 & $\begin{array}{c}26.3 \\
84\end{array}$ & $\begin{array}{c}.003 \\
\text { b }\end{array}$ \\
\cline { 2 - 7 } & $\begin{array}{c}\text { Resid } \\
\text { ual }\end{array}$ & 5.264 & 114 & .112 & & \\
\cline { 2 - 7 } & Total & 18.957 & 117 & & & \\
\hline \multicolumn{6}{|c|}{ a. Dependent Variable: organizational performance } \\
\hline \multicolumn{6}{|c|}{ b. Predictors: (Constant), Employee recognition } \\
\hline
\end{tabular}

Source: Researcher (2021)

The result in table 4 above was interpreted based on the significance of the $F$ value. If the significance of the $F$ value was less than 0.05 , then the model would be considered to be significant and vice versa. Because the significance value is 0.003 , the model is statistically significant when it comes to forecasting the impact of staff recognition initiatives on an organization's productivity. The F value was 26.384 when viewed at a $5 \%$ level of significance. The whole model was significant since the F computed was bigger than the F crucial $(\mathrm{p}$ value $=3.555)$.

Table 5: Coefficients

\begin{tabular}{|c|c|c|c|c|c|c|}
\hline \multicolumn{7}{|c|}{ Coefficients $^{\mathrm{a}}$} \\
\hline & \multirow{2}{*}{ Model } & \multicolumn{2}{|c|}{$\begin{array}{l}\text { Unstandardized } \\
\text { Coefficients }\end{array}$} & \multirow{2}{*}{$\begin{array}{c}\begin{array}{c}\text { Standa } \\
\text { rdized } \\
\text { Coeffi } \\
\text { cients }\end{array} \\
\text { Beta }\end{array}$} & \multirow{2}{*}{$\mathrm{t}$} & \multirow{2}{*}{ Sig. } \\
\hline & & B & $\begin{array}{l}\text { Std. } \\
\text { Error }\end{array}$ & & & \\
\hline \multirow{5}{*}{1} & & .525 & .491 & & 2.293 & .000 \\
\hline & & .839 & .138 & 2.708 & $2 . .817$ & .005 \\
\hline & (Constant) & .525 & .109 & 4.455 & 2.357 & .002 \\
\hline & \multirow{2}{*}{ Recognition } & -.649 & .110 & 1.067 & 1.446 & .000 \\
\hline & & .759 & .082 & 3.789 & -1.520 & .001 \\
\hline & \multicolumn{6}{|c|}{$\begin{array}{c}\text { Dependent Variable: organizational performance } \\
\text { Source: Researcher (2021) }\end{array}$} \\
\hline
\end{tabular}


The established regression equation by the study was $\mathrm{Y}=$ $0.525+0.839 \mathrm{X}_{1}$.

Where:

$\mathrm{X}_{1}$ is recognition of employees

From the above regression model, holding recognition constant performance of organization would be 0.525 . As shown in table 5 indicating that the independent variable has effect on the performance of organization. 0.525 is the value of organization performance when employee recognition strategies is zero. Thus from the regression model recognition, work life balance, personal career development and health benefit had a positive and significant effect in organization performance as indicated by their $\mathrm{t}$-values.

\section{Recognition}

Recognition had a positive and significant effect on performance of organization as indicated by their $\mathrm{t}$-values ( $\mathrm{t}=$ $2.817, \mathrm{p}<0.05)$. It was also found to have a greater $(83.9 \%)$ influence on the performance of organization

\section{SUMMARY OF FINDINGS}

Organisations' performance in Kenya improved considerably as a result of recognition, according to the research's t-values $(t=2.817, p 0.05)$. The majority of respondents strongly agreed with the statements that benefits that employees are supposed to receive are paid promptly, with a mean score of 4.11 and a standard deviation of 0.840 , while the second-highest mean score of 3.81 and a standard deviation of 1.015 demonstrated that employee recognition is associated with improved organizational performance. In addition to receiving regular paychecks $(\mathrm{M}=3.42, \quad \mathrm{SD}=1.024), \quad$ employees are also adequately compensated $(\mathrm{M}=3.39, \mathrm{SD}=0.979)$ for their contributions to the company's success.

\section{CONCLUSIONS}

The research comes to the conclusion that recognition is critical in improving employee performance, which in turn improves the performance of the firm. It is emphasized in the research that the significance of an employee being acknowledged quickly is one of the strong parameters to assess employee recognition on the success of a business. In addition, the researchers discovered that workers' performance would improve if they are properly and promptly rewarded for their efforts. The research comes to the conclusion that recognition, whether monetary or non-financial, has a significant influence on the overall performance of workers in a business.

\section{RECOMMENDATIONS}

According to the findings of the study, MEWASS management should seek to create a work-life balance that attracts, retains, and inspires its employees so that they may work in a positive environment that promotes organizational performance. If organizations in Kenya wish to encourage and improve the performance of their workers, they should place a greater emphasis on intrinsic recognitions rather than monetary awards. Organizational long-term success is dependent on a well-designed recognition system that is proportional to the level of performance achieved by its employees.

According to the research, Kenyan businesses should provide their workers with options for personal professional progression. Personal career progression is beneficial to both the company as a whole and the individual member of the workforce. It will have a detrimental influence on the company's overall performance if it has an employee who routinely performs below par. According to the survey, organizations in Kenya should effectively manage their workers' health benefits in order for them and their families to stay healthy. It is possible that the overall performance of a corporation may increase as a consequence of these efforts.

\section{Recommendations for Further Studies}

There should be more research on the impact of staff recognition tactics on organizational success in various industries. Additional research on the impact of employee diversity on organizational success are also needed.

\section{REFERENCES}

[1] Allen, D. G., Renn, R., \& Griffeth, R. W. (2003). Generational contrasts, indicators and fulfillment results. Human resource management and personnel science research.

[2] Boyens, M. (2007). Hierarchical socialization, vocation yearnings and turnover Intentions among configuration engineers. Authority and Organization Development Journal, Emerald Group Publishing Limited

[3] Breaugh, J. A., \& Starke, M. (2000). Research on employee recruitment: So many studies, so many remaining questions. Journal of management, 26(3), 405-434.

[4] Breaugh, J. A., and Frye, N. K. (2008). Work-family struggle: The significance of family-accommodating business practices and family strong directors.

[5] Harris, J. (2000). Finding and keeping incredible representatives." Strategies for endurance in battle of ability

[6] Herzberg, G., \& Howe, L. L. (1959). The Lyman bands of molecular hydrogen. Canadian Journal of Physics, 37(5), 636-659.

[7] Horton, S. (2007). Presentation the skill based development: Its starting points and effect on the public area.

[8] Ming, F. (2008) Work-family struggle and work-family collaboration for age X, people born after WW2 and develops: Generational contrasts, indicators and fulfillment results.

[9] Mitchell, T.R., and Erez, M. (2001). Why individuals stay: Using position embeddedness to anticipate deliberate turnover. Institute of Management.

[10] Ndungu .D.N (2017). Work-family struggle and work-family collaboration for age X, people born after WW2 and develops: Generational contrasts, indicators and fulfillment results.

[11] Nyanjom .C.R (2013). Drivers of balance between fun and serious activities: An empirical examination dependent on information from CAC GO Company. College of France: Unpublished Masters of Human Resource Management Thesis.

[12] Ongori, H. (2009). Overseeing in the background: A view point on worker strengthening. African Journal of Business Management.

[13] Orodho, A. J. (2009). Elements of Education and Social Science Research Methods: Maseno. Kenya: Kanezja Publishers.

[14] Robbins, S.P. (2003). Authoritative Behavior: Concepts, Controversies and Applications. $8^{\text {th }}$ Edition. London: Prentice Hall. 